\title{
Evaluation of Effects of Synthetic Compound and Mineral Admixture on Crystal Structure of Concrete
}

\author{
Samuel Oloruntoba Olugbenga Olusunle*, Theresa Chikwuo Ezenwafor, \\ Bidemi Sikirat Jiddah-Kazeem, Akeem Kareem, Ojo Jeremiah Akinribide, \\ Adekunle Taofeek Oyelami \\ Engineering Materials Development Institute, Akure, Nigeria \\ Email: tolusunle@yahoo.co.uk
}

Received 16 March 2015; accepted 27 March 2015; published 31 March 2015

Copyright (C) 2015 by authors and Scientific Research Publishing Inc.

This work is licensed under the Creative Commons Attribution International License (CC BY). http://creativecommons.org/licenses/by/4.0/

(c) (i) Open Access

\begin{abstract}
The effects of mineral admixture on the internal morphology of concrete were studied and evaluated in this work. Portland cement with five different additives was used in the complex admixture. These includes: extracted silica from corn hob ash, synthetic calcium carbonate, synthetic calcium hydrogen carbonate, white and dark kaolin, each replacing $10 \%$ of cement in the concrete formulation. The additives and the pure cements were subjected to intensive mixing to ensure homogeneity prior to water addition, after which each undergoes casting and curing. Elemental characterizations of the additives indicated the presence of some elemental oxides and crystallography studies were carried out on the pure and reinforced concrete. The obtained result indicated crystallographic adjustments of the indigenous concrete which will definitely contribute to modifying its mechanical properties.
\end{abstract}

\section{Keywords}

Synthetic Carbonates, Crystallography, Elemental Characterization

\section{Introduction}

It is an established fact that the strength of concrete determines its area of applications. However, strength and stress distribution within any material is a function of its internal morphology [1]. It is reported that the finer the constituents forming a material, the stronger (but relatively brittle) the material will be. On the other hand, ac-

${ }^{*}$ Corresponding author.

How to cite this paper: Olusunle, S.O.O., Ezenwafor, T.C., Jiddah-Kazeem, B.S., Kareem, A., Akinribide, O.J. and Oyelami, A.T. (2015) Evaluation of Effects of Synthetic Compound and Mineral Admixture on Crystal Structure of Concrete. Journal of Minerals and Materials Characterization and Engineering, 3, 134-141. http://dx.doi.org/10.4236/jmmce.2015.33016 
cording to [2], the coarser these constituents are, the weaker (but relatively tough) they are. Moreover, the unique strength of High Strength Concrete (HSC) has been attributed to its internal structures among other things. For example, varying particle sizes and sizes distribution affect the densification of concrete, hence having net effect on the overall concrete [3].

The prime need of concrete design and quality control has been to ascertain and specify the strength of HSC, and so does the need to investigate the causes of the high strength according to [4]. Various parameters such as cement type, water/cement ratio, aggregate type and grading, mineral admixtures, chemical additives, curing conditions and age of concrete etc. influence the strength of HSC by altering morphological status of the concrete, thus resulting in concrete most suitable for a given application. To this effect, various adjustments aimed at modifying concrete morphology, so that desired properties can be attained. These adjustments include: using various particle sizes in aggregate, additives/admixtures, altering curing condition to mention a few.

Even though altering curing condition and the use of chemical additives to rectify and modify concrete morphology are vita, relatively high cost and time consumption (in altered curing condition) limited these processes to only when becoming unavoidable as in the case of high-rise buildings, building superstructures of long-span bridges etc. as in [5]. However, the use of organic additive proves to be promising especially that they are known as "environmental waste" [5].

The area involving the uses of admixtures in concrete reinforcement is a field enjoying high visitation in the light of research; among the established additives are Mineral Admixtures (MAs). These additives (majorly contain silicon oxide and are either pozzolanic or both pozzolanic and cementitious to a degree) were utilized for the production of HSC. The silica when added during grinding process modifies the surface of the cement particles and also promotes the formation of highly reactive amorphous structure. It also acts as micro-filler and participates in pozzolanic reactions, and results in production of high performance cement [6]. It has been possible to produce concrete mixes in laboratory conditions using such MAs that produced a compressive strength which exceeded $180 \mathrm{MPa}$. The primed strength in some tall buildings has attained a compressive strength of approximately $125 \mathrm{MPa}$ [7]. According to [8], his studies of the permeability and resistance to sulphate attack and alkali-aggregate reactivity of Portland cement found that the concrete paste mixed with the silica exhibits higher strength than the conventional one. [8] documented a test where $16 \%$ and $25 \%$ of cement used in the paste and mortar (measured by mass) were replaced by Silica Fume additives (SF). Their results showed that the partial replacement of cement by SF increased the compressive strength of mortar. Lam et al. (1998) studied the effect of replacing cement by flying ash (FA) and SF with different w/c ratios of $0.30,0.40$ and 0.50 . They noticed that FA improved the post-peak compressive behaviour. Shannagin [9] stated that the addition of 15\% pozzolan and $15 \%$ SF to concrete resulted in a $26 \%$ increase of the 28-day compressive strength of concrete. For mixes with a w/cm ratio of 0.35 , the strength of the SF concrete was found to be higher than the strength of the concretes without SF.

Even though successes recorded are numerous and established when additives are to improve concrete, there is a need to go beyond such additions. This is because there is a high dependence of concrete properties on the relationship between internal morphology and external force. Hence the present research is intended at investigating the effect of mineral admixture on crystallography of concrete. This will provide a guide on the operation and mechanisms upon which these additives operate in concrete improvement.

\section{Material and Method}

\subsection{Sourcing of Materials and Elemental Characterization}

The materials used in the study includes Portland cement type 1, conforming to ASTM C150 which most predominant in country. Extracted silica from corn hob ash, synthetic calcium carbonates, calcium hydrogen carbonate, natural white and dark kaolin were the added additives. The concrete ingredients, especially the waste used for this study are representative of materials typically available in Nigeria whereas the synthetic salt is product of Sigma Aldrich. According to [10] each of the dried materials was crushed and ball milled with 9VS model to smaller particle size, in order to enhance homogeneity, the sample was sieved using an Octagon Digital sieve shaker to a particle size of 150 micron in each sample.

The oxides of elemental composition of the cement and the additives were determined using EDXRF Spectrometer (EDX 3600B) with an exception of the synthetic calcium carbonate and calcium hydrogen carbonate. 


\subsection{Mixing and Casting of the Concrete}

Cement was replaced, by weight, with 10 percentages of each additive during dry mixing; water was added to mix incrementally to attain the consistency and slump required. Water needed for the mix was adjusted based on the absorption of aggregate. Also time, sequence and method of mixing the aggregates and additives for each sample remained unchanged. The mixing lasted for about 10 minutes after which the fresh concrete was casted, allowed to set at a room temperature of about $25^{\circ} \mathrm{C}$ in the laboratory for 24 hours, and then finally cured under atmospheric conditions for 5 days.

\subsection{Crystallography}

The spectrum and data of the pure and reinforced concrete was obtained using Enhanced Mini-Materials Analyzer (EMMA) X-Ray diffractometer while the crystallography study was done using the software containing the data base supplied by the International Centre for Diffraction Data (ICDD).

\section{Result and Discussion}

\subsection{Elemental Characterization}

The data and spectrum of metal oxide composition of the pure cement and the additives are presented in Table 1, respectively. The obtained result showed that the pure concrete has about 36\% of Calcium oxide. Apart from the extracted silica that gave $63 \%$ of $\mathrm{SO}_{2}$, the $\mathrm{KWH}$ and $\mathrm{KDA}$ have higher content of silica of about $15.95 \%$ and $16.58 \%$ respectively. High content of aluminium oxide was observed in the XRF result of white and dark kaolin while the dark kaolin contains the highest content of iron oxide. An oxide of sulphur was high in the pure cement. The variations in the percentage compositions of the oxides of these elements in the additives have been attested to contribute to the change in the concrete crystallography. The elemental compositions of the synthetic calcium carbonate and calcium hydrogen carbonate were not carried out since it a known compound.

Table 1. The elemental oxide composition of pure concrete and additives (\%).

\begin{tabular}{ccccc}
\hline Elemental Oxides & $\mathrm{CEM}$ & $\mathrm{KWH}$ & $\mathrm{KDA}$ & $\mathrm{SiO}_{2}$ \\
\hline $\mathrm{MgO}$ & 0.1758 & 0.0000 & 0.0000 & 0.0000 \\
$\mathrm{Al}_{2} \mathrm{O}_{3}$ & 1.6875 & 11.4326 & 7.0164 & 0.0056 \\
$\mathrm{SiO}_{2}$ & 3.9319 & 15.9536 & 16.5804 & 63.8287 \\
$\mathrm{P}_{2} \mathrm{O}_{5}$ & 0.2650 & 0.1243 & 0.1241 & 0.1854 \\
$\mathrm{SO}_{3}$ & 2.9771 & 0.2877 & 0.2465 & 0.5713 \\
$\mathrm{~K}_{2} \mathrm{O}$ & 0.0000 & 0.2016 & 0.4981 & 0.0215 \\
$\mathrm{CaO}$ & 36.1396 & 0.0414 & 0.2405 & 0.6759 \\
$\mathrm{TiO}_{2}$ & 0.0000 & 0.5714 & 0.1251 & 0.0000 \\
$\mathrm{~V}_{2} \mathrm{O}$ & 0.0053 & 0.0165 & 0.0137 & 0.0074 \\
$\mathrm{Cr} \mathrm{O}_{3}$ & 0.0022 & 0.0018 & 0.0120 & 0.0066 \\
$\mathrm{MnO}$ & 0.0064 & 0.0081 & 0.0335 & 0.0208 \\
$\mathrm{Co}_{2} \mathrm{O}_{3}$ & 0.0038 & 0.0065 & 0.0285 & 0.0106 \\
$\mathrm{FeO}$ & 0.9572 & 1.9289 & 8.8614 & 1.9481 \\
$\mathrm{Ni}_{2} \mathrm{O}$ & 0.0508 & 0.0817 & 0.0722 & 0.0694 \\
$\mathrm{CuO}$ & 0.0537 & 0.0844 & 0.0689 & 0.0835 \\
$\mathrm{ZnO}$ & 0.0918 & 0.1321 & 0.1231 & 0.1616 \\
$\mathrm{AsO}$ & 0.0000 & 0.0000 & 0.0000 & 0.0000 \\
$\mathrm{PbO}$ & 0.0097 & 0.0045 & 0.0082 & 0.0000 \\
$\mathrm{~W}$ & 0.0720 & 0.0551 & 0.1129 & 0.2231 \\
$\mathrm{Au}$ & 0.0000 & 0.0000 & 0.0849 & 0.0000 \\
$\mathrm{Ag} 2 \mathrm{O}$ & 0.0046 & 0.0086 & 0.0081 & 0.0000 \\
$\mathrm{Rb}$ & 0.0000 & 0.0011 & 0.0045 & 0.0091 \\
\hline
\end{tabular}

Key: $\mathrm{CEM}=$ Pure cement, $\mathrm{KDA}=$ Dark kaolin, $\mathrm{KWH}=$ White kaolin, $\mathrm{SiO}_{2}=$ Extracted silica. 


\subsection{Crystallography}

Figures 1-6 presented the spectrum of pure and reinforced concrete. The obtained result showed that the spectrum of the control differs from the spectra of the reinforced concrete. The disappearance and appearance of some peaks (breaking and formation of bonds) indicates that chemical reactions (especially hydration) took place between some active ingredient in the additives and that of the pure concrete, hence will have effect on the

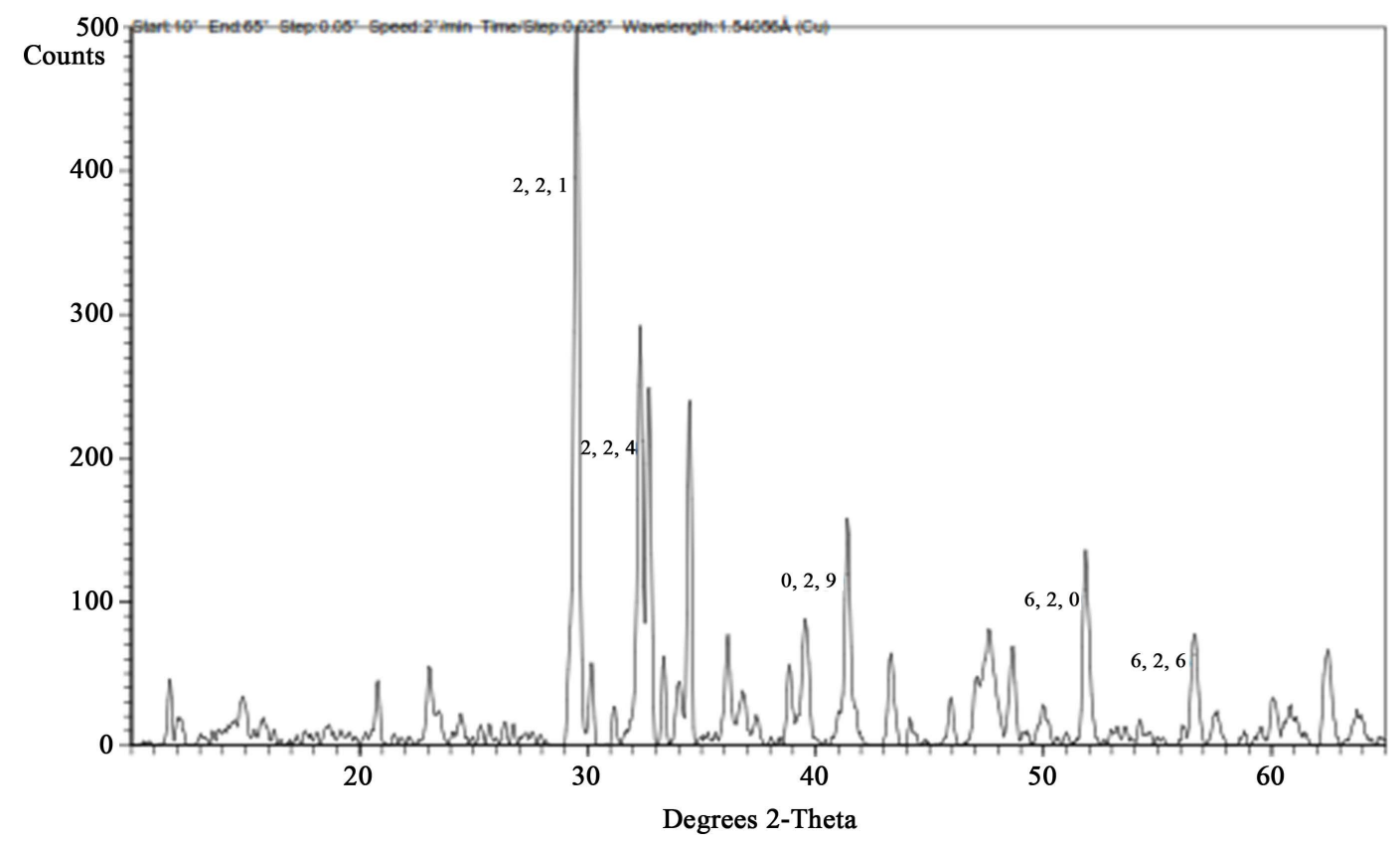

Figure 1. XRD spectrum of CEM.

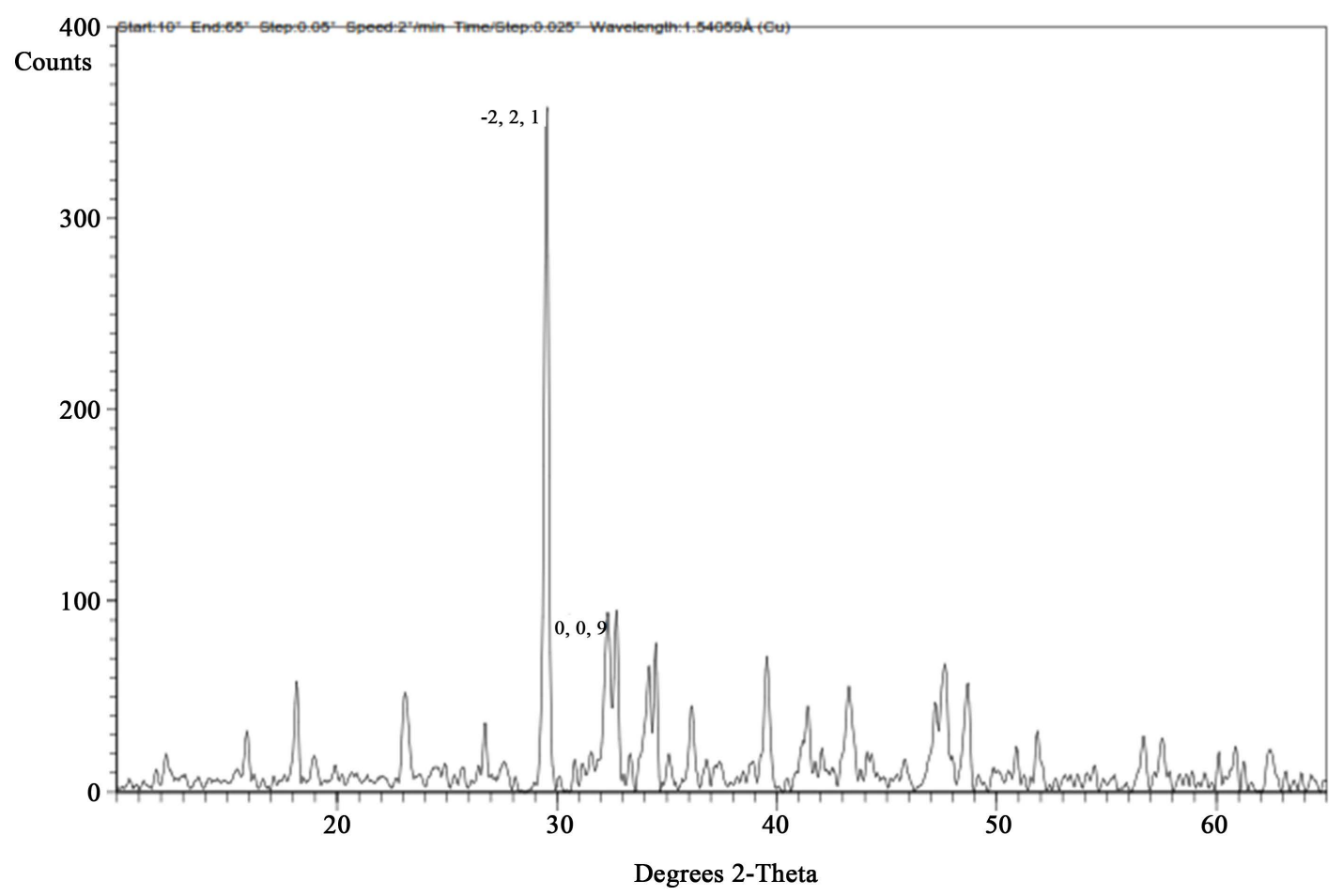

Figure 2. XRD spectrum of CEM + KDA. 


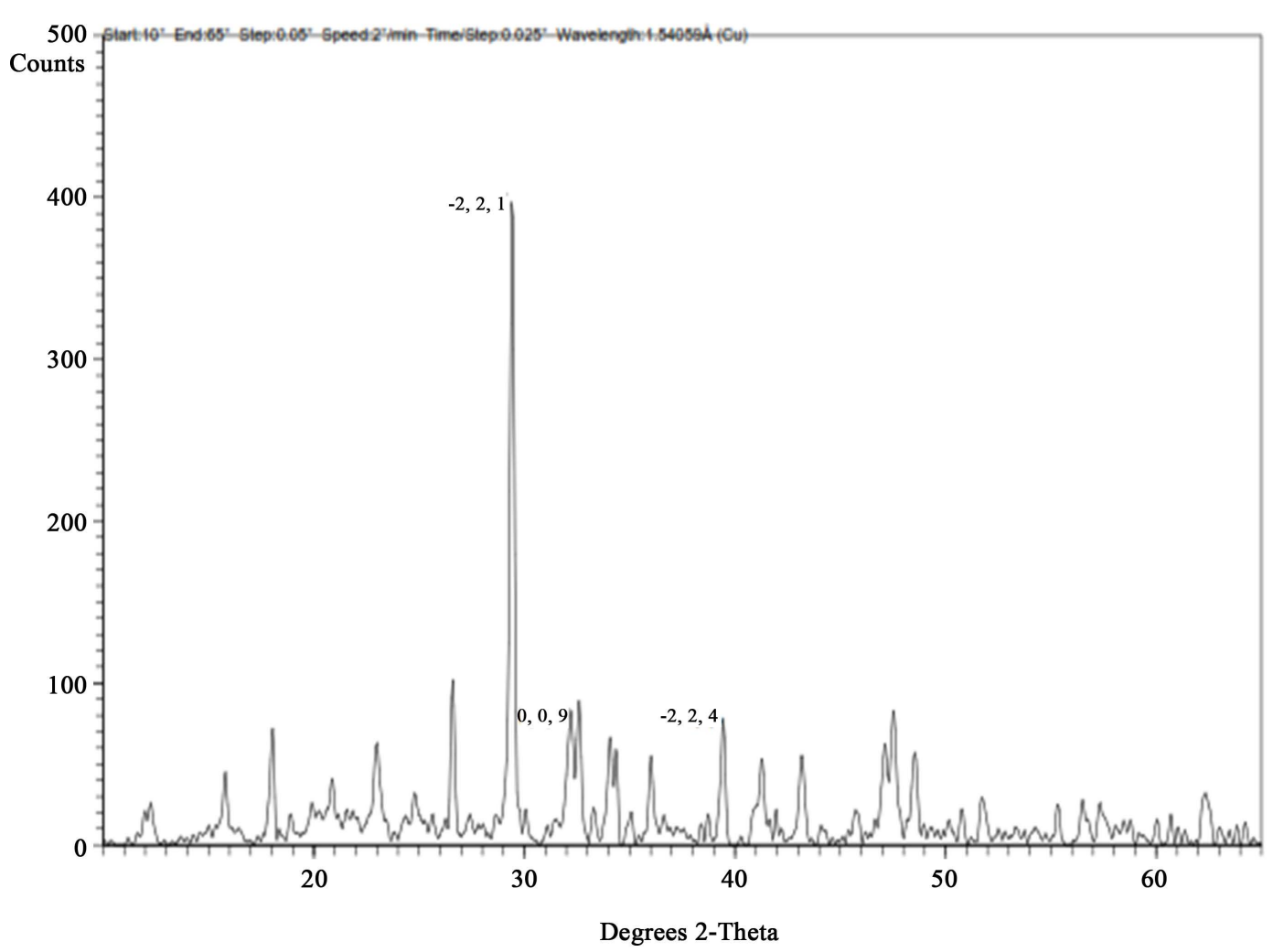

Figure 3. XRD spectrum of CEM + KWH.

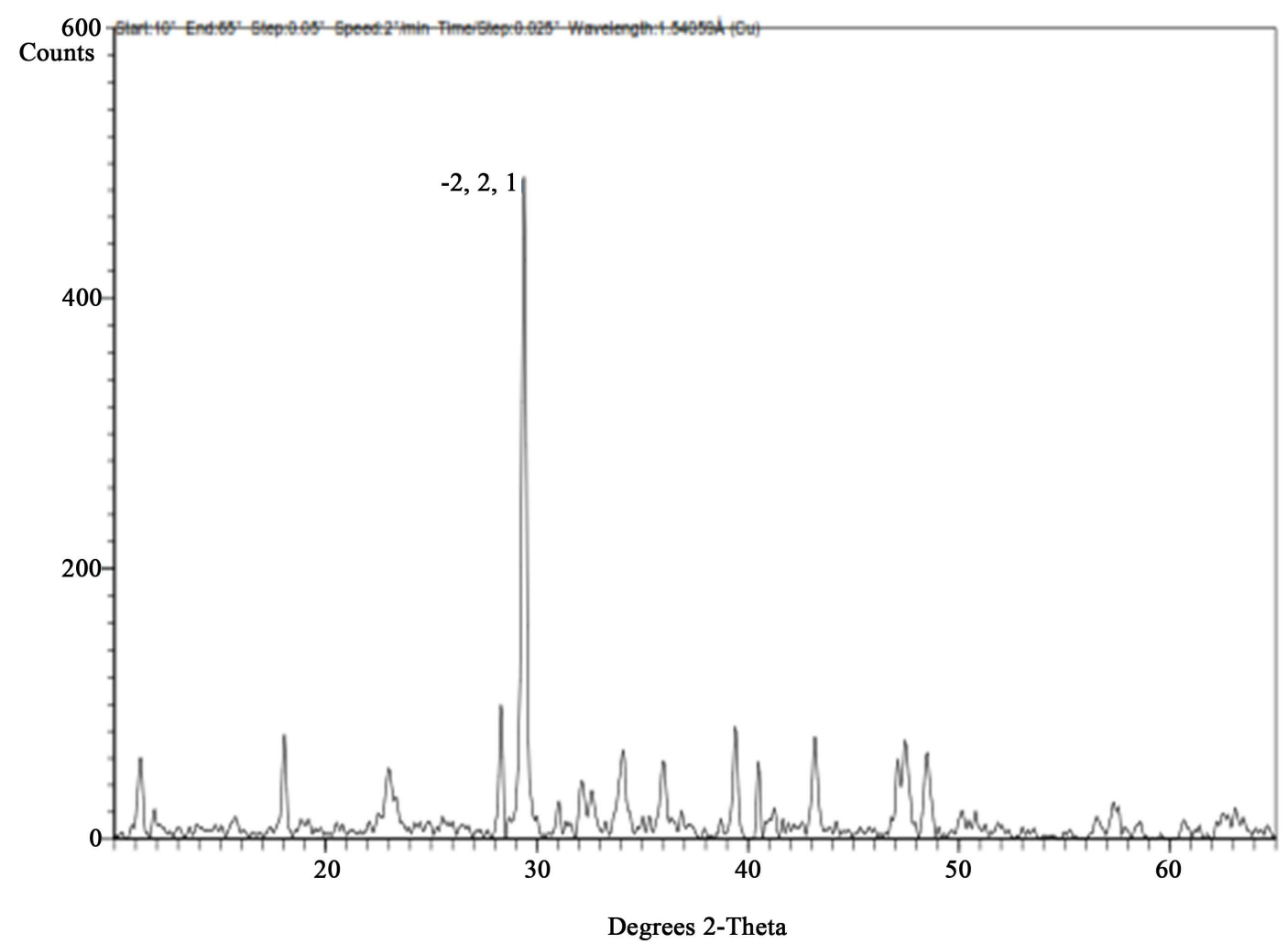

Figure 4. XRD spectrum of $\mathrm{CEM}+\mathrm{SiO}_{2}$. 


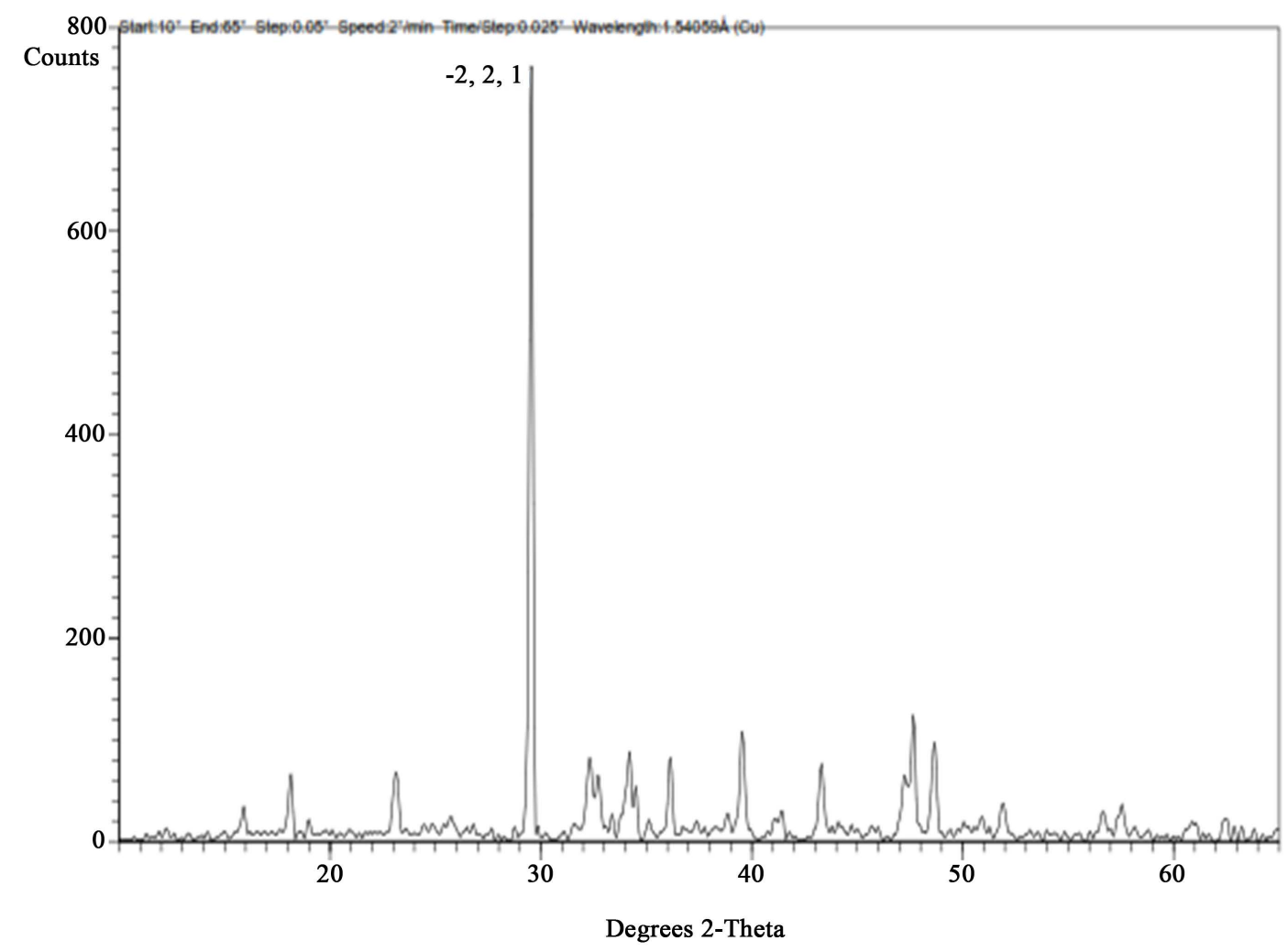

Figure 5. XRD spectrum of $\mathrm{CEM}+\mathrm{Ca}_{2} \mathrm{CO}_{3}$.

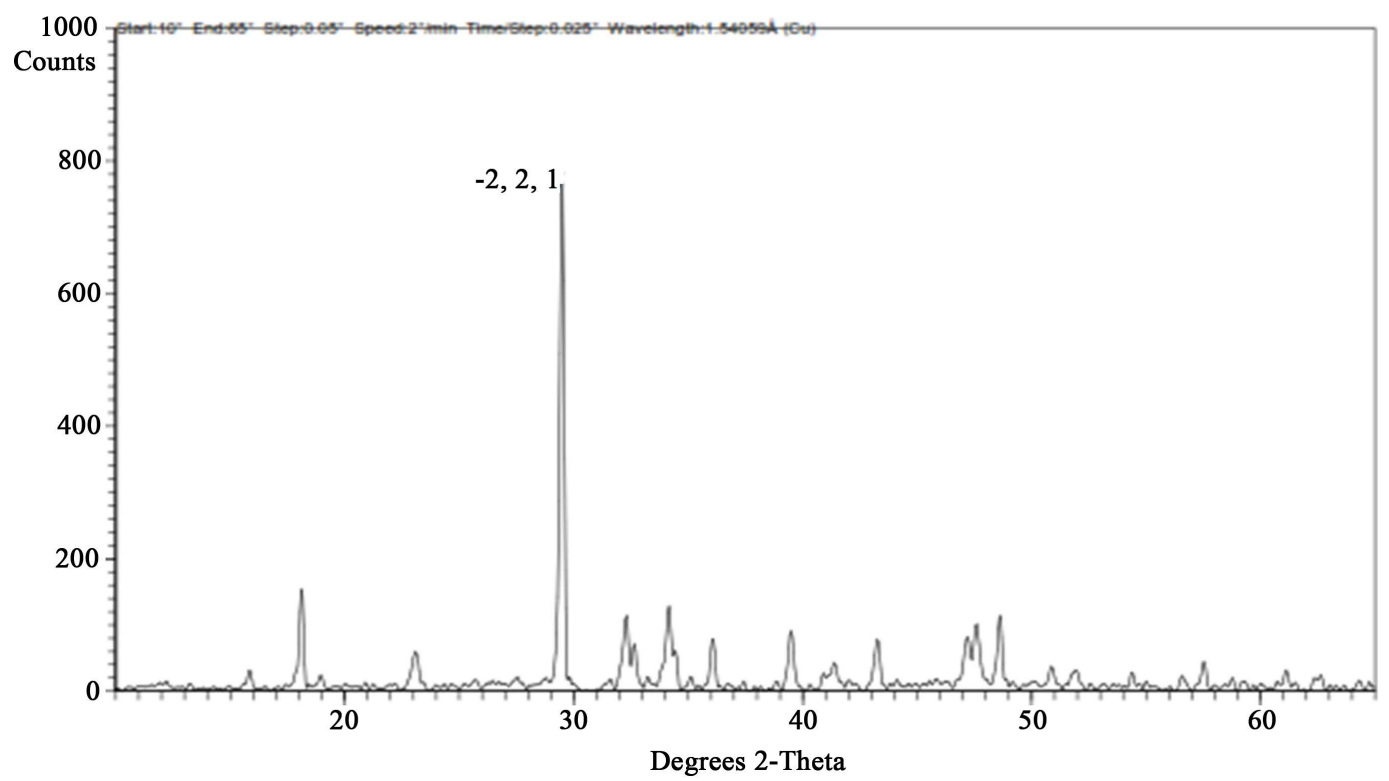

Figure 6. XRD spectrum of $\mathrm{CEM}+\mathrm{CaHCO}_{3}$.

mechanical properties (Figure 1). Hydration process transform complex particle from different size and shape to another form with different phase. Apart from the spectra of CEM + KDA which shows more bond formation (presence of many weak peaks) that might be as a result of some organic materials, other additive indicated more bond breaking. The peak within the range of $29.6^{\circ}$ of the $2 \theta$ remain constant in the spectra of all the reinforced concrete though some appeared more crystalline and showed increase in their intensity. The spectra of 
CEM + KWH showed the formation of pronounced new crystalline peak with intensity of $160 \%$ at angle $2 \theta$ of about $26.5^{\circ}$. In addition, $\mathrm{CEM}+\mathrm{CaHCO}_{3}$ spectrum shows formation of new peaks at about $18.5^{\circ}$ and gradual disappearance of peaks from 2 theta angle of $35^{\circ}$ and above. It was observed that the higher the content of $\mathrm{SiO}_{2}$ in each additive, the higher the intensity of the peak values as can be observed from the spectra. The analyses carried out on the obtained spectrums using International Center for Diffraction Data (ICDD) software shows that pure cement has lattice plane with five miller indices ( $\mathrm{h} \mathrm{l}$ ) values which correspond to that on the standard (JCPDS card no: 00-013-0272). Reinforcement of the pure cement shifted the peak angles with only $2 \theta$ angle of $29.56^{\circ}$ prominent in all and has lattice plane with miller indices of $-2,2,1$ proving the reaction that took place.

Moreover, the crystallographic study (Table 2) has indicated that incorporation of additives to concrete affects its lattice structure. The analyzed peaks on the pure cement shows two prominent chemical compositions at

Table 2. The result of crystallographic study of pure concrete and admixtures.

\begin{tabular}{|c|c|c|c|}
\hline Sample Code & Peak Position $(2 \theta)$ & Chemical Compositions at the Phases & Crystal Structure \\
\hline \multirow{2}{*}{ CEM } & $29.5223^{\circ}, 32.3133^{\circ}, 38.8512^{\circ}$ & $\mathrm{Ca}_{3} \mathrm{SiO}_{5}$ & Anorthic (Triclinic) \\
\hline & $31.151^{\circ}, 36.8605^{\circ}, 39.5528^{\circ}, 45.924^{\circ}, 62.4577^{\circ}$ & $\mathrm{Ca}_{3}\left(\mathrm{H}_{6} \mathrm{Si}_{2} \mathrm{O}_{7}\right) \mathrm{OH}$ & Monoclinic \\
\hline \multirow{5}{*}{$\mathrm{CEM}+\mathrm{CaHCO}_{3}$} & $41.45^{\circ}, 57.55^{\circ}$ & $\mathrm{CaSiO}_{3}$ & Triclinic \\
\hline & $23.15^{\circ}, 39.5045^{\circ}, 47.25^{\circ}$ & $\mathrm{CaSiO}_{3}$ & Monoclinic \\
\hline & $41.45^{\circ}, 43.308^{\circ}$ & $(\mathrm{MgFe})_{5} \mathrm{Si}_{6} \mathrm{O}_{16}(\mathrm{OH})_{2}$ & Monoclinic \\
\hline & $32.3113^{\circ}$ & $\mathrm{SiO}_{2}$ & Tetragonal \\
\hline & $29.5083^{\circ}$ & $\mathrm{Ca}_{3} \mathrm{SiO}_{3}$ & Anorthic (Triclinic) \\
\hline \multirow{9}{*}{$\mathrm{CEM}+\mathrm{KWH}$} & $33.329^{\circ}, 45.80^{\circ}, 48.50^{\circ}, 51.70^{\circ}$ & $\mathrm{CaSiO}_{3}$ & Triclinic \\
\hline & $39.4595^{\circ}$ & $\mathrm{Ca}_{3} \mathrm{SiO}_{5}$ & Triclinic \\
\hline & $22.9915^{\circ} 24.7965^{\circ}$ & $(\mathrm{MgFe})_{5} \mathrm{Si}_{6} \mathrm{O}_{16}(\mathrm{OH})_{2}$ & Monoclinic \\
\hline & $19.9423^{\circ}, 29.4382^{\circ}, 55.45^{\circ}$ & $\mathrm{Ca}_{3}\left(\mathrm{Si}_{3} \mathrm{O}_{8}(\mathrm{OH})_{2}\right)$ & Triclinic \\
\hline & $18.057^{\circ}, 29.4382^{\circ}$ & $\mathrm{SiO}_{2}$ & Tetragonal \\
\hline & $26.60^{\circ}, 36.0318^{\circ}$ & $\mathrm{Si}_{96} \mathrm{O}_{192}$ & Tetragonal \\
\hline & $48.5878^{\circ}, 56.6982^{\circ}$ & $\mathrm{SiO}_{2}$ & Orthorhombic \\
\hline & $56.6982^{\circ}, 57.4578^{\circ}$ & $\mathrm{CaSiO}_{3}$ & Monoclinic \\
\hline & $18.087^{\circ}, 26.60^{\circ}, 29.4382^{\circ}$ & $\mathrm{SiO}_{2}$ & Tetragonal \\
\hline \multirow{6}{*}{$\mathrm{CEM}+\mathrm{SiO}_{2}$} & $47.4758^{\circ}$ & $\mathrm{CaSiO}_{3}$ & Triclinic \\
\hline & $28.3328^{\circ}$ & $\mathrm{Ca}_{5}\left(\mathrm{SiO}_{4}\right)_{2}(\mathrm{OH})_{2}$ & Monoclinic \\
\hline & $31.05^{\circ}, 32.176^{\circ}$ & $(\mathrm{MgFe})_{17} \mathrm{Si}_{20} \mathrm{O}_{54}(\mathrm{OH})_{6}$ & Orthorhombic \\
\hline & $39.4427^{\circ}$ & $(\mathrm{MgFe})_{5} \mathrm{Si}_{6} \mathrm{O}_{16}(\mathrm{OH})_{2}$ & Monoclinic \\
\hline & $18.0657^{0}, 29.418^{0}, 40.5235^{0}$ & $\mathrm{SiO}_{2}$ & Tetragonal \\
\hline & $48.5298^{0}$ & $\mathrm{Si}_{96} \mathrm{O}_{192}$ & Tetragonal \\
\hline \multirow{6}{*}{$\mathrm{KD}+\mathrm{CEM}$} & $23.1155^{\circ}, 36.1278^{\circ}, 56.70^{\circ}$ & $\mathrm{Si}_{96} \mathrm{O}_{192}$ & Tetragonal \\
\hline & $35.15^{\circ}, 44.20^{\circ}$ & $(\mathrm{MgFe})_{5} \mathrm{Si}_{6} \mathrm{O}_{16}(\mathrm{OH})_{2}$ & Monoclinic \\
\hline & $29.52^{\circ}$ & $\mathrm{Ca}_{3} \mathrm{SiO}_{5}$ & Anorthic \\
\hline & $34.15^{\circ}$ & $\mathrm{SiO}_{2}$ & Tetragonal \\
\hline & $50.85^{\circ}$ & $\mathrm{CaSiO}_{3}$ & Monoclinic \\
\hline & $51.88^{\circ}, 60.85^{\circ}$ & $\mathrm{Ca}_{3}\left(\mathrm{Si}_{3} \mathrm{O}_{8}(\mathrm{OH})_{2}\right)$ & Triclinic \\
\hline \multirow{7}{*}{$\mathrm{CaCO}_{3}+\mathrm{CEM}$} & $15.90^{\circ}, 23.12^{\circ}$ & $\mathrm{Si}_{96} \mathrm{O}_{192}$ & Tetragonal \\
\hline & $25.75^{\circ}$ & $\mathrm{SiO}_{2}$ & Orthorhombic \\
\hline & $28.85^{\circ}$ & $\mathrm{CaSiO}_{3}$ & Monoclinic \\
\hline & $29.51^{\circ}, 32.32^{\circ}, 33.70^{\circ}, 38.85^{\circ}, 51.90^{\circ}$ & $\mathrm{Ca}_{3} \mathrm{SiO}_{5}$ & Triclinic \\
\hline & $35.10^{\circ}$ & $(\mathrm{MgFe})_{5} \mathrm{Si}_{6} \mathrm{O}_{16}(\mathrm{OH})_{2}$ & Monoclinic \\
\hline & $36.12^{\circ}$ & $(\mathrm{MgFe})_{17} \mathrm{Si}_{20} \mathrm{O}_{54}(\mathrm{OH})_{6}$ & Orthorhombic \\
\hline & $39.55^{\circ}$ & $\mathrm{SiO}_{2}$ & Tetragonal \\
\hline
\end{tabular}


different phases and crystal lattice structure of triclinic and monoclinic. But the reinforced concrete showed more than two crystal structures; the $\mathrm{CE}+\mathrm{KWH}$ for instance contains additional crystal lattices like tetragonal and orthorhombic. It made up of the same chemical compositions of the same crystal structure at different phases while some has different chemical composition of the same crystal structure at different phases. Some of the compound observed to be presence in some of the reinforced cement includes $\left(\mathrm{MgFe}_{17} \mathrm{Si}_{20} \mathrm{O}_{54}(\mathrm{OH})_{6}\right.$ and $\mathrm{SiO}_{2}$. In all, it was observed that compound of the same chemical compositions though formed at different phases gave the same lattice structure (as can be observed from the Table 2.

\section{Conclusion and Recommendation}

The investigation has demonstrated that reinforcing pure cement with additives especially white kaolin, extracted silica, periwinkle shell and calcium carbonate has effects on its lattice structure. With the present day technology, the study has shown that it is possible to produce a concrete which is more durable using indigenous and waste materials in Nigeria. This not only will yield concrete that has better properties, but also will be cost-effective and affordable.

Narrowing down this present study, using abundant indigenous and waste materials—white kaolin, dark kaolin and extracted silica from corn hob ash is highly recommended. Special attention is to be paid on the effect of parameters which include particle sizes, concrete variations and void formations in order to come up with a prospective specification and standardized method. Moreover, studying the effects of these additives on the mechanical properties of the concrete is very important.

\section{References}

[1] Awang, H., Mydin, Md.A.O. and Roslan, A.F. (2012) Effect of Additives on Mechanical and Thermal Properties of Lightweight Foamed Concrete. Advances in Applied Science Research, 3, 3326-3338.

[2] Lam, L., Wong, Y.L. and Poon, C.S. (1998) Effects of Fly Ash and Silica Fume on Compressive and Fracture Behavior of Concrete. Journal of Cement and Concrete Research, 28, 271-283. http://dx.doi.org/10.1016/S0008-8846(97)00269-X

[3] Langan, B.W., Weng, K. and Ward, M.A. (2002) Effect of Silica Fume and Fly Ash on Heat of Hydration of Portland Cement. Journal of Cement and Concrete Research, 32, 1045-1051. http://dx.doi.org/10.1016/S0008-8846(02)00742-1

[4] Ramachandran, V.S. (1995) Concrete Admixture Handbook. Noyes Publication, New Jersey.

[5] Ismeik, M. (2009) Effect of Mineral Admixtures on Mechanical Properties of High Strength Concrete Made with Locally Available Materials. Jordan Journal of Civil Engineering, 3, 78-90.

[6] Sobolev, K. (2003) Effect of Complex Admixture on Cement Properties and the Development of Test Procedure for the Evaluation of High Strength Cement. Advances in Cement Research, 15, 1-9. http://dx.doi.org/10.1680/adcr.2003.15.2.67

[7] Haque, M.N. and Kayali, O. (1998) Properties of High-Strength Concrete using a Fine Fly Ash. Journal of Cement and Concrete Research, 28, 1445-1452. http://dx.doi.org/10.1016/S0008-8846(98)00125-2

[8] Shannag, M.J. (2000) High Strength Concrete Containing Natural Pozzoland and Silica Fume. Journal of Cement and Concrete Composites, 22, 399-406. http://dx.doi.org/10.1016/S0958-9465(00)00037-8

[9] Toutanji, H.A. and El-Korchi, T. (1996) Tensile and Compressive Strength of Silica-Fume Cement Pastes and Mortars. Journal of Cement, Concrete and Aggregates, 18, 78-84. http://dx.doi.org/10.1520/CCA10154J

[10] Batrakov, V.G. (1990) Modified Concrete. Stroyizdat, Moscow, 6-37. 